This PDF is a selection from an out-of-print volume from the National Bureau of Economic Research

Volume Title: Long-Range Economic Projection

Volume Author/Editor: Conference on Research in Income and Wealth

Volume Publisher: NBER

Volume ISBN: 0-691-04141-5

Volume URL: http://www.nber.org/books/unkn54-1

Publication Date: 1954

Chapter Title: Conceptual Problems Involved in Projections of the International Sector of Gross National Product

Chapter Author: Jacques J. Polak

Chapter URL: http://www.nber.org/chapters/c2939

Chapter pages in book: (p. 377 - 424) 


\title{
CONCEPTUAL PROBLEMS INVOLVED IN PROJECTIONS OF THE INTERNATIONAL SECTOR OF GROSS NATIONAL PRODUCT
}

\author{
J A C Q U S J. POLAK \\ INTERNATIONAL MONETARY FUND
}

\section{A. THE INTERNATIONAL SECTOR IN GNP TABULATIONS}

\section{The smallness of "net foreign investment"}

IN THE typical tabulation of the gross national product of the United States, ${ }^{1}$ the international sector is summarized by the heading "net foreign investment." In magnitude, the item is small in most normal years, and in many abnormal years as well. In 1949, it was $\$ 422$ million against a GNP of $\$ 256$ billion. In the 21 years from 1929 through 1949, net foreign investment exceeded 1 percent of GNP only five times. Its statistical unimportance, as measured by its presentation in the GNP tables of the Department of Commerce, may further be inferred from the fact that it was smaller than the "statistical discrepancy" in 16 of the same 21 years. In 8 of these years, the statistical discrepancy would have been smaller if net foreign investment had not been added into GNP (Table 1).

It is to this very small item that this paper is addressed. But before proceeding to a discussion of the techniques of projection in the international sector, it will be necessary to clarify the nature of the item. In the process, we shall also make clear that the smallness is in part arbitrary and the result of the stepchild treatment which this particular item appears to have received from national income statisticians. ${ }^{2}$

\section{Treatment of the foreign sector on a net basis}

The first arbitrary reason why the foreign element in the social

Note: The author is an official of the International Monetary Fund. The views expressed in this paper are his own.

I See, for instance, Survey of Current Business, "National Income Number," July 1950 (Department of Commerce).

${ }^{2}$ In fact, the foreign sector played an even smaller role in the first national income estimates of the Department of Commerce, when only the net of dividends and interest was included as an entry, "International Balance of Property Income," the last line on income paid out by "Miscellaneous Industries." See National Income in the United States, 1929-35 (Department of Commerce, 1936), p. 232. 
TABLE 1

Gross National Product, Net Foreign Investment, and "Statistical Discrepancy," 1929-49

(IN BILLIONS OF DOLLARS)

\begin{tabular}{lccc}
\hline Year & $\begin{array}{c}\text { Gross National } \\
\text { Product }\end{array}$ & $\begin{array}{c}\text { Net Foreign } \\
\text { Investment }\end{array}$ & $\begin{array}{c}\text { "Statistical } \\
\text { Discrepancy" }\end{array}$ \\
\hline 1929 & 103.8 & 0.8 & -0.1 \\
1930 & 90.9 & 0.7 & -0.7 \\
1931 & 75.9 & 0.2 & 1.2 \\
1932 & 58.3 & 0.2 & 1.4 \\
1933 & 55.8 & 0.2 & 1.2 \\
1934 & 64.9 & 0.4 & 0.9 \\
1935 & 72.2 & -0.1 & -1.3 \\
1936 & 82.5 & -0.1 & 0.9 \\
1937 & 90.2 & 0.1 & 1.1 \\
1938 & 84.7 & 1.1 & -0.1 \\
1939 & 91.3 & 0.9 & 1.4 \\
1940 & 101.4 & 1.5 & 1.6 \\
1941 & 126.4 & 1.1 & 1.6 \\
1942 & 161.6 & -0.2 & 2.3 \\
1943 & 194.3 & -2.2 & 0.9 \\
1944 & 213.7 & -2.1 & 4.0 \\
1945 & 215.2 & -1.4 & 4.9 \\
1946 & 211.1 & 4.6 & 1.7 \\
1947 & 233.3 & 8.9 & 0.3 \\
1948 & 255.1 & 1.9 & -2.9 \\
1949 & 255.6 & 0.4 & -1.9 \\
\hline
\end{tabular}

Source: Survey of Current Business, "National Income Number," July 1950 (Department of Commerce).

accounts appears relatively so small is that a general tendency to move in the direction of more "gross" concepts in the national income field has (at least in the United States) stopped short of the foreign sector. ${ }^{3}$ In Kuznets' article on "National Income" in the Encyclopaedia of Social Sciences, one still finds national income defined essentially as what is now called "personal disposable income." Taking this definition of national income as a starting point, we could write according to the now customary formulae: ${ }^{4}$

"Many European countries show the foreign sector "gross"; for example, Denmark, France, the Netherlands, Norway, and Sweden. Sweden, among others, shows invisibles "net," but some countries provide gross figures for the entire foreign sector.

^ Corporate undistributed profits and similar refinements are omitted here. 
National income $=$ Consumption + net home investment + government deficit + net foreign investment

In this equation, which one also finds implicit or explicit in the early writings of the Keynes school, all three items-home investment, the government deficit, ${ }^{5}$ and foreign investment-are on a net basis. Gradually, however, the tendency of national income statisticians seems to have been to "gross up" the two former items. Home investment was made gross by adding depreciation on both sides of the equation; the government section, by adding government receipts and taxes on both sides. Taking these two steps in reverse order, we first add, on the left, taxes to disposable income and obtain national income; and on the right, taxes to the government deficit and obtain governmental expenditure:

National income $=$ Consumption + net home investment + government expenditure + net foreign investment

Then we add depreciation to both sides:

Gross national product $=$ Consumption + gross home investment + government expenditure + net foreign investment

The reader conversant with modern national income details will observe many omissions in these equations-indirect taxes, transfer payments, etc. These have been omitted purposely so as not to clutter up the picture and so as to simplify the point which is to be made: that in "grossing up" the national income concept, only the foreign sector has been left out.

Services and donations ${ }^{\theta}$ apart, net foreign investment equals exports minus imports. It often strikes the not quite so sophisticated reader as odd that in order to arrive at national income or at GNP, one should deduct imports. The answer is that imports are included in the other elements on the right-hand side of the equation, and that they have to be excluded to arrive at the net domestic value added of the consumption goods, investment goods, and export industries.

But the same sort of argument which leads to the inclusion of depreciation lends support to the idea of not deducting the import component in the output of consumer goods, investment goods, and exports. At the last stage of the grossing up process,

"Which Robertson called "honorary investment." See "Mr. Clark and the Foreign Trade Multiplier," Economic Journal, Vol. xLxx, June 1939.

- We shall discuss donations below. 
we come to what might-if a term is needed-be called gross output: ${ }^{7}$

Gross output $=\mathrm{GNP}+$ import of goods and services $=$ Gross value of home consumption + gross value of home investment + gross value of exports

Though I do not want to press too strongly for yet another member of the already proliferating family of national income concepts, the preceding paragraphs will have made clear that one reason why the foreign sector looks disproportionately small in total GNP is the net procedure presently followed with respect to that sector. ${ }^{8}$

\section{Elimination of donations from the foreign sector}

The second reason why, at least in postwar years, the foreign sector appears so small lies in the treatment of international donations in GNP. In the absence of donations, the surplus on account of goods and services in the balance of payments must be equal to net foreign investment-although each can be measured separately and the difference between the two, if any, usually called "errors and omissions," need not necessarily be allocated to the capital sector of the balance of payments as is implied in the present treatment in the GNP calculations in the United States.

It should be noted that, even in that situation, "net foreign investment" enters into GNP, not because investment in foreign countries has anything to do with the GNP of the United States, but simply because of the numerical equality of net foreign investment to the surplus on account of goods and services. It is this surplus which is the real component of GNP.

If the surplus is met in part by donations, such as European Recovery Program aid or emigrants' remittances, instead of by

7 This concept differs from that of "Gross Available Resources" as used in a number of countries in that the latter is obtained by deducting exports and hence equals GNP + Imports - Exports. See National Income Statistics, 1938-1947 (United Nations, 1948).

8 The practice of treating both the government sector and the foreign sector on a net basis has led to the parallel development in both fields of confused and indeed wrong ideas-the ideas that only a govermment deficit or only an export surplus could be expansionary-which have only recently been corrected. Cf. Trygve Haavelmo, "Multiplier Effects of a Balanced Budget," Econometrica, October 1945, and J. J. Polak, "The Foreign Trade Multiplier," American Economic Review, Vol. xxxvu, No. 5, December 1947. 


\section{THE INTERNATIONAL SECTOR}

changes in the United States foreign assets and liabilities position, so that net foreign investment is no longer equal to the surplus of goods and services, the proper entry is the surplus and not net foreign investment. Obviously, it makes no difference to activity and income in the United States whether exports are financed by a United States loan or paid in gold (both cases of net foreign investment), or whether they are given away as a grant. Nonetheless, it is net foreign investment and not the surplus on goods and services which appears on the United States GNP account. Why?

The explanation for this can be found in the treatment of other sectors of the economy in GNP accounting. It can most readily be explained by reference to the very simplified balance of payments presented below. In this presentation all transactions in goods and services are combined and, also for simplicity, donations to the United States are left out of account.

\section{United States Balance of Payments \\ Debit \\ Credit}

Goods and services (G\&S) Goods and services (G\&S)

Commercial imports, G\&S $M \quad$ Commercial exports, G\&S $E_{1}$ Gift exports, G\&S

i. Government

ii. Private $E_{2}$

Donations

Government
i. $\mathrm{G} \& \mathrm{~S}$
$E_{2}$
ii. Cash
$D_{1}$

Private

i. $G \& S$

ii. Cash

Capital (net)

Net foreign investment

$E_{3}$
$D_{2}$

Capital (net)

On the basis of these entries, the net surplus on account of goods and services, which may be considered as the element of GNP associated with the foreign sector, equals $E_{1}+E_{2}+E_{3}-M$. The "net foreign investment" which is actually entered into the GNP calculations by the equality of the two sides of the balance of payments ${ }^{9}$ equals $E_{1}-M-D_{1}-D_{2}$. Hence, it is lower than

-Assigning "errors and omissions" somewhat arbitrarily to the capital account. 
the surplus on goods and services by the deduction of all donations, both in kind and in cash. This treatment is made possible by the entries under "government expenditure" and "personal consumption expenditure." Gift exports from the United States ${ }^{10}$ financed by government grants are entered as government purchases of goods and services, whether technically they are purchased by the government or not. Gift parcels sent by private persons or through such organizations as CARE are lumped together with (or, more accurately, not distinguished from) personal purchases for domestic consumption. Governmental grants abroad in cash, such as Economic Cooperation Administration dollars made available for procurement in Latin America, are fictitiously entered under "government purchases from abroad." Private cash remittances abroad are, again fictitiously, entered as a specified item of personal consumption, in the general group of "foreign travel and remittances." It will be seen that, by this procedure-matching these scattered items against the net foreign investment item-the addition made to GNP is the same as if all four items were omitted from government and private consumption expenditure, and the net surplus on account of goods and services were entered into GNP.11

Here, as in the previous section, there is no one particular treatment which can claim to be the most rational. In order that the difference between government expenditure and government receipts equal changes in the government debt (and similar items), it is necessary to enter both $E_{2}$ and $D_{1}$ under government expenditure. If personal income minus personal expenditure is to equal personal saving, $E_{3}$ and $D_{2}$ must be listed as personal expenditure. But, similarly, if the balance of payments is to balance, donations must be entered into it. If all this is done, however, and the surplus on account of goods and services is entered as an element of GNP, all donation items are counted twice.

There are various solutions to this problem of double counting. The one followed in the United States GNP computation is to keep the government and private sections of the social accounts in balance, but to rearrange the balance of payments in such a way as to avoid the double counting and, in the process, to make it virtually unrecognizable as a balance of payments. Thus, while

10 Such gifts in kind purchased abroad by the U.S. Government are entered under purchases from abroad.

$11 E_{1}-M-D_{1}-D_{2}+\left(E_{2}+D_{1}+E_{3}+D_{2}\right)=E_{1}+E_{2}+E_{3}-M$. 
one can perhaps still understand the treatment of governmental grants in cash as "government purchases from abroad" in the government account, it becomes a little hard to recognize the same item when presented as "sales to United States government" in the account "transactions of the rest of the world with the United States." Clearly the more elegant solution would be to have all three accounts-the government account, the personal account, and the balance of payments-in a form in which each can be read and understood by itself, and to take care of the double counting by an adjustment entry in the GNP total.

\section{Foreign aspect of net foreign investment}

Even including donations, however, the surplus on goods and services is still a relatively minor factor in relation to the total United States GNP. But, in considering the importance of projecting this element of GNP, we must bear in mind that from an entirely different point of view it is considered a crucial magnitude. The same magnitude-or a closely related magnitudewhich carries the colorless name of "net U.S. foreign investment" in the GNP context appears with the flashing title of the "world's dollar shortage" in connection with the major payments problems of the world. The "dollar shortage" can be defined in various ways. ${ }^{12}$ It may, for instance, be defined as (1) the surplus of the United States balance of payments on goods, services, and private donations, which is equal to net United States foreign investment plus net official United States foreign grants, or as (2) the amount of "compensatory official financing" 13 in the United States balance of payments, which differs from the definition under (1) primarily in that it deducts the net outflow of capital from the United States on private account and on government account for special purposes. Whatever the precise definition chosen, the dollar shortage, as an ex post statistical concept, tends to come close to the net foreign investment item in GNP, especially if foreign grants are included in this item rather than in government expenditure. While, for national income purposes, the projection of the net foreign investment item may be of relatively minor importance, the accurate forecasting of the balance of payments of the United

\footnotetext{
12 Fritz Machlup, “Three Concepts of the So-Called 'Dollar Shortage," Economic Journal, Vol. Lx, March 1950, pp. 46-68.

${ }^{13}$ International Monetary Fund, Balance of Payments Yearbook, 1938, 1946, 1947.
} 
States is of cardinal importance in connection with the world's payments problems.

It is important in this connection to stress that the benefit which foreign countries derive from their relations with the United States do not arise primarily from the United States export surplus of goods and services, but from the gross total of dollars made available through United States imports plus grants. ${ }^{14}$ The elasticity of demand for a good part of the imports from the United States, such as essential foodstuffs and many types of machinery, is small. The elasticity of supply of many commodities exported to the United States is also small, at least in the short run. Accordingly, the gains from trade with the United States on the intramarginal units are very considerable and may well be larger than the gains from additional free imports out of grants. In addition, many countries limit their imports from the United States below the level of market demand at the existing rate of exchange for the dollar-or, in other words, maintain their exchange rate (in terms of units of national currency for one dollar) below the equilibrium rate. In these circumstances, there is a gain even on the marginal trade. ${ }^{15}$

\section{5. "Supply of dollars"}

To indicate this gross concept of the purchasing power over United States goods and services made available to the rest of the world, the term "supply of dollars" has been frequently used in recent years. This supply of dollars was defined originally ${ }^{\mathbf{1 6}}$ as the gross purchases of goods and services, plus private donations, plus the gross outllow of long-term capital. It would, in terms of the postwar situation, require to be amended to include governmental grants as well.

This concept of the supply of dollars, whatever its precise definition, had the advantage of bringing into focus two important aspects which, while not novel, need stressing: (a) that the demand for United States goods and services, i.e., the demand for

14 United States capital is left out of consideration for a moment. It will be brought in presently.

${ }^{15}$ For the underlying concepts see, e.g., Sidney S. Alexander, "The Relative Cost of Devaluation and Import Restriction as Instruments for Improving the Foreign Trade Balance," International Monetary Fund, Staff Papers, Vol. r, No. 3.

${ }_{18} \mathrm{Hal}$ B. Lary, The United States in the World Economy (Government Printing Office, 1943). 
U.S. dollars, can never be considered independently of the supply of dollars by the United States; and (b) that in this supply of dollars, the supply through United States lending of capital is of very great importance, next to the supply by the United States purchase of goods and services.

Both points may require some important qualifications which are of particular importance in the context of the recent postwar years, although, strictly speaking, they also applied earlier. ${ }^{17}$ In the first place, the supply of dollars, as a factor influencing, though not uniquely determining, the demand for dollars, should not be considered as equal to the current flow of dollars to foreign countries, but consideration should also be given to the stock of dollars, gold, and various other assets in the hands of foreign countries. The observation is similar to that applicable to the explanation and forecasting of total consumption in the postwar years; we should not only use the variable "income," which, on the whole, gave a satisfactory explanation before, but should take account of the consumers' accumulated stock of money and "near money." A particular feature of the postwar demand for United States exports was that international reserves, which were actually low in real terms by prewar standards, became excessive in view of the greatly impoverished situation and the urgent needs of the war-stricken foreign countries.

Secondly, it should be stressed that while there are important similarities between the supply of dollars through the purchase by the United States of foreign goods and services, on the one hand, and the export of United States capital, on the other hand, there are also very important differences. The most important difference is that no current resources have to be given in return for dollars obtained by a loan. A second difference is the restriction on dollars obtained through certain loans. Thus loans by the Export-Import Bank are "tied"-i.e., usable only for purchases in the United States-by practice or by law. On account of institutional ties, direct investments by United States companies are likely to lead to exports from the United States rather than from other countries.

For this latter reason, a given amount of additional dollar supply provided by increased United States imports will have a

17 On these points, ef. J. H. Adler, "The Postwar Demand for U.S. Exports," Review of Economic Statistics, Vol. xxvII, February 1946, pp. 23-33. 
greater effect ${ }^{18}$ in reducing the "dollar shortage" than the same additional supply provided by capital exports. The latter will tend to lead to more "new" demand for imports from the United States, caused by the limitations (legal, contractual, or practical) on the use of these dollars by the country receiving them and will hence contribute correspondingly less to the reduction of the dollar shortage which previously existed. For purposes of policy, therefore, foreign lending or capital exports by means of direct investment of $x$ million dollars is not a substitute for increased United States imports of the same amount.

\section{Items to be considered}

While net foreign investment may be entered into a tabulation of GNP estimated for the future on a net basis, this net figure will always have to be derived on a gross basis. It is not intended in this paper to discuss every item of the United States balance of payments, but rather to concentrate on those important items on which it may be possible to shed some additional light. The discussion will be limited, therefore, to imports (Section B), exports (Section C), and official loans and grants (Section D). We shall omit both services and private donations and capital movements. ${ }^{19}$

In the treatment to be followed, we shall use without much distinction the expressions "explanation," "forecast," and "projection." Most forecasting consists in the extrapolation of a relationship; and the same relationship, read with reference to the past, must represent a satisfactory explanation of the variable we want to forecast, if we are to use the relationship with confidence in regard to the future.

\section{B. IMPORTS}

\section{The standard explanation}

Ever since Professor Paish ${ }^{20}$ coined the term "marginal propensity

18 Abstracting from the effect of increased income abroad on demand for imports-a point discussed below.

${ }_{19}$ There is no implication, as Mr. Fabricant seems to suggest in his Comment, that these latter flows are less independent, or of denying their importance or their interrelation with imports and exports. They are omitted simply to limit the discussion. The issue of causal or definitional equality is, therefore, not at all at stake here.

$20 \mathrm{~F}$. W. Paish, "Banking Policy and the Balance of International Payments," Economica, Vol. III (N.S.), November 1936, pp. 404-22. 
to import," the relationship between fluctuations in income and fluctuations in imports has received a good deal of statistical attention from economists. Taking into account, also, the more classical factor of relative prices as a determinant of imports, a number of attempts have been made in the last 10 years to explain, statistically, fluctuations in United States imports by reference to (a) United States national income or a closely related variable and (b) the relative prices of imports and United States commodities. Usually these calculations have been made in "real" terms, i.e., the volume (quantum) of imports has been explained in terms of fluctuations in real income. Table 2 gives the result of a number of these correlations.

TABLE 2

United States Demand for Imports

\begin{tabular}{lccccc}
\hline Author & Source $^{\mathrm{a}}$ & Period & $\begin{array}{c}\text { Income } \\
\text { Elasticity }\end{array}$ & $\begin{array}{c}\text { Price } \\
\text { Elasticity }\end{array}$ & $\begin{array}{c}\text { Multiple } \\
\text { Correlation }\end{array}$ \\
\hline deVegh & 1 & $1919-40$ & $0.7 \mathrm{~b}$ & - & 0.90 \\
Chang & 2 & $1924-38$ & 1.27 & -0.97 & 0.95 \\
Adler & 3 & $1922-37$ & 1.01 & -0.09 & 0.92 \\
Chang & 4 & $1919-39$ & 0.89 & -0.01 & 0.84 \\
\hline
\end{tabular}

a Sources: (1) Imre deVegh, "Imports and Income in the United States and Canada," Review of Econumic Statistics, 1941, pp. 130-46; (2) T. C. Chang, "International Comparison of Demand for Imports," Review of Economic Studies, 1945-46, pp. 53-67; (3) J. H. Adler, "United States Import Demand during the Interwar Period," American Economic Review, 1945, pp. 418-30; and (4) T. C. Chang, unpublished study prepared at the International Monetary Fund (1948).

b Elasticity with respect to industrial production index.

Taking this collection of correlations (which cover practically the same period and, with the exception of the first, use very similar data) as a whole, the results are not too satisfactory. The correlations, while high, still leave something to be desired; the income elasticity shows some uncertainty, and the price elasticity appears to be altogether uncertain.

Similar calculations were made by Chang, ${ }^{21} \mathrm{R}$. Hinshaw, ${ }^{22}$ and the United States Department of Commerce ${ }^{23}$ for the five main classes of United States imports. Perhaps the most striking

21 Sources 2 and 4 of Table 2.

22 Unpublished study of the Federal Reserve Board.

${ }^{23}$ Survey of Current Business, July 1946 (Department of Commerce), p. 18. 
aspect of these correlations for the various classes is that the fit is generally a good deal less satisfactory than for imports as a whole, although the groups themselves are large enough for us to expect cancellation within them of accidental fluctuations.

When postwar national income data were substituted in these correlations for total imports and for the five classes of imports, they were widely used as a yardstick of comparison between actual imports in 1946, 1947, and 1948 and "expected" or "calculated" imports for these years. ${ }^{24}$

The differences between the actual and the calculated data have been differently interpreted. Thus, allowance has been made for decreased rubber and silk imports caused by the production of synthetic rubber and rayon and nylon. But on the whole these calculations were, for a long time, used as forecasts, if not of the actual, then at least of the normal, imports into the United States at given levels of income. Thus, in February 1949, the Survey of Current Business wrote, under a caption "Imports Still Relatively Low": ${ }^{25}$

"Despite their high dollar value and their larger volume as compared with 1947, commodity imports in 1948 were, in real terms, only 5 per cent above previous high levels reached in 1929 and 1937. On the basis of the prewar relationship between domestic economic activity and imports, at least 1.8 billion dollars of additional imports could have been absorbed here in 1948.

"... Although actual imports were somewhat closer to calculated imports in the first three quarters of 1948 than in 1947, there was still a large deficiency of imports from Europe and a smaller, though substantial, lack of imports from Asia. After omitting from the calculation for Asia imports of raw silk which has been displaced to a large extent by the use of synthetic fibers, and 250,000 short tons of rubber, the legal minimum volume for domestic synthetic rubber production, the apparent deficiency in imports from Asia and Europe was about 2.5 billion dollars. On the other hand, actual imports from other areas, particularly North America, were about 0.7 billion dollars in excess of the value projected on the 1921-38 relationship between gross national product and imports from those continents.

"The large discrepancy between actual and calculated imports

24 "The Balance of International Payments of the United States, 1946-48," Survey of Current Business, July 1946 and February 1949 (Department of Commerce).

25 Pp. 30-31. 
from Europe was mainly in finished and semi-manufactured goods, those economic classes of imports which showed the greatest deficiency. . . . At the same time, the deficiency in imports from Asia was apparently greatest in crude materials and manufactured foodstuffs, although for crude materials as a whole the deficiency (excluding silk and 250,000 tons of rubber) was more than compensated for by increased imports from South America and Africa.

"Such a development indicates that the 1921-38 relationship for certain economic classes or areas has been somewhat modified and that imports from the Western Hemisphere and Africa may well remain higher than the amount calculated on the basis of historical relationships, because of our increased dependence upon foreign sources for commodities such as nonferrous metals and petroleum."

It may be noted that, while it is admitted that the relationship for imports from the Western Hemisphere may have changed permanently, there is no suggestion that the same applies to Europe or Asia.

The recession of 1949 , when the decline in industrial activity in the United States produced at once a decline in imports (including imports from Europe), might well have shattered the myth of the "shortage of imports," and should have made it obvious that the prewar relationship had been broken and that a new relationship had been reestablished on a considerably lower level. Nevertheless, the Department of Commerce, while far more careful and stressing in detail the replacement of imports by domestic production, still concludes that "it is difficult to say whether the future American market for foreign goods may be understated or overstated by projections derived from past relationships between imports and gross national product."."26

\section{Inadequacies of the approach}

Surveying these results, we can hardly consider them as satisfactory. All we have by way of explanation of this variable, which is of crucial importance, not only for the United States, but also for the rest of the world, is a number of rather simple explanations of either an aggregate or its standard subdivision into five categories. These correlations have been used widely as (quali-

${ }^{26}$ The Balance of International Payments of the United States, 1946-1948 (Department of Commerce, 1950), p. 60. 
fied) forecasts and, while they have failed to yield good forecasts, they have not (like the early postwar unemployment forecasts) been entirely discarded. ${ }^{27}$ It seems useful, therefore, to stress some of the weaknesses of these explanations.

\section{Weaknesses in the correlation}

In the first place, the correlations for the interwar period appear to have been as high as they were in part by accidental circumstances. Adler ${ }^{28}$ recently found the high correlation coefficient between real GNP and the volume of imports of $0.99^{29}$ for the years 1923 to 1937 to be to a large extent "the result of two unique events-the repeal of prohibition in 1933 and the serious drought of 1934-37-which caused United States imports to be larger at

${ }^{27}$ Attention may be drawn here to a general theory as to the fate of forecasts which are not confirmed by events. If the event forecast was a bad event-such as the postwar unemployment-which does not materialize, the forecaster is blamed and the forecast forgotten. But if the event is a good event-more dollar exports for Europe-the forecast remains alive, though it tends to become a target rather than a forecast; and the blame for nonfulfillment, if any, attaches not to the forecaster, but to the economic group which should have done more to bring about the good event. The following quotation from the source quoted in the previous footnote is instructive in this connection:

"By contrast, projections made on the basis of prewar experience may overstate the demand in this country for traditional imports from Asia and Europe. Our markets for major interwar exports from Asia, such as silk, rubber, and burlap, were particularly affected by the large-scale use of domestically produced substitutes. At the same time, the products of United States factories also competed far more effectively than before the war with imports of manufactured goods from Europe. An additional development, which may continue to cause lower than prewar imports from these areas relative to domestic incomes was the shift during the war and postwar years from European and Far Eastern countries as sources for certain United States import commodities (see above) to Western Hemisphere countries and Africa, and the emigration of many workers with special skills to the United States or other non-European countries.

"It is possible and even probable, however, that Far Eastern and European export industries may be able to surmount many of these handicaps to traditional exports by greater output and reduced prices, and by appealing to quality preferences of American consumers. The revival and modernization of export industries abroad, and the heretofore unequaled efforts to stimulate exports to this country by means such as the assignment of priorities to export industries and market research, may well result in the expansion of other new types of exports to the United States to offset relative declines in sales of other products to this country."

${ }^{28} \mathrm{John}$ H. Adler, Eugene Schlesinger, and Evelyn Van Westerborg, "The Pattern of United States Import Trade since 1923, Some New Index Series and Their Application" (Federal Reserve Bank of New York, 1952).

29 This correlation is apparently a different one from that referred to in Table 2. 
the end of the period than they would have otherwise been. If that part of the increase in imports between 1933 and 1937 which was caused by these two random factors is removed from the series, the coefficient of correlation of imports with gross national product falls to +.83 . This adjustment obviously influences any projections of the postwar level of imports to gross national product. Total United States imports for 1948, as estimated from the experience of the interwar period, would be $\$ 1,630$ million smaller when adjustments are made to take account of the effects of the drought and the repeal of prohibition than when no such correction is made, and would to that extent be closer to actual imports in that year." Thus, the very premise that we had a "good" explanation of U.S. imports, which could with confidence be extrapolated, needs questioning.

It would seem, also, that it will be necessary to deepen our insight into the factors which caused fluctuations in imports and thus to arrive at better explanations and more reliable forecasts.

\section{Downward trend in U.S. imports}

For the relatively short interwar period on which the existing correlations are based, it was possible to explain fluctuations in imports without the use of a trend factor. Nevertheless the existence of such a trend, at least in the long run, would seem to be plausible and to require investigation before interwar relationships are applied to forecast imports for a period some 20 years later. Thus, the expansion of the American market made possible the economic production within the country of goods previously imported. The stream of migration brought to the United States skills whose products had previously to be bought from abroad. Probably most important, the increase in per capita income directed an increasing proportion of consumption toward services which, while some of them can be imported in the form of tourist services, in any case do not enter into the statistics of commodity imports. It is not surprising, therefore, that the ratio of United States imports to GNP has so far shown a pretty persistent tendency to decline (Table 3 ).

Table 3 (which is in terms of values and therefore not directly comparable with the correlations underlying the forecasts, all of which were in real or quantity terms) shows a number of interesting features. Taking the 80 -year period as a whole, there is a striking decline to about one-third in imports, compared with 
TABLE 3

Ratio of IMPORTS to GNP, 1869-1949

(IN CURRENT DOLLARS)

\begin{tabular}{cc}
\hline Annual Averages & Imports as Percent of GNP \\
\hline $1869-78$ & 7.2 \\
$1879-88$ & 6.1 \\
$1889-98$ & 6.3 \\
$1898-1908$ & 4.6 \\
$1909-18$ & $5.0^{\mathrm{a}}$ \\
$1920-29$ & $4.4^{\mathrm{b}}$ \\
$1930-39$ & $2.8^{\mathrm{b}}$ \\
1937 & 3.4 \\
$1946-49$ & $2.5^{\mathrm{b}}$ \\
\hline
\end{tabular}

at would not seem that this figure was high on account of the war years. For the partly overlapping decade $1904-13$, the ratio was 4.8 percent.

b Average of percentages for individual years.

Source: Report to the President on Foreign Economic Policies (Gray Report) (Government Printing Office), p. 124 and sources mentioned there.

GNP. ${ }^{30}$ This decline is, however, by no means smooth. Thus, despite the interruption of many commercial ties in World War I and the persistence of the secular tendencies mentioned, the ratio for the twenties was not much lower than it had been in the early part of the century. The sharp break between the twenties and the thirties may in part be because of the increased tariff. Lastly, the postwar figures appear to be not far below the average of the thirties. But this may well be because of the fact that the four postwar years were all boom years (by the standards of the thirties). Compared with the last previous boom year, 1937, the average postwar percentage was about one-fourth off (2.5 percent as against 3.4 percent).

There is, in any case, sufficient statistical evidence of the existence in the past of a downward trend in imports compared with GNP to make it necessary to allow for this trend in forecasting.

\section{Inventory cycles and imports}

The regression coefficients found by correlating imports and national income over the interwar period have been mostly determined by the major waves of that period: the rise in the twenties, the decline from 1929 to 1932 or 1933 , and the recovery thereafter. For these major swings the income elasticity of demand

${ }^{30} \mathrm{~A}$ forecaster in the seventies who had been told that the 1949 GNP would be over $\$ 250$ billion might have forecast imports at $\$ 18$ billion. 
for imports (in real terms) appears to have been close to unity. But inspection of the data shows that the elasticity is far greater for shorter cycles. Thus real GNP increased by about 4 percent from 1936 to 1937 and then declined again by about 4 percent from 1937 to 1938. But the volume of imports increased by 11 percent and then fell by 38 percent, indicating an average elasticity over this short cycle of something like 6. Again, in the short recession in 1949, when real GNP declined only a few percent even on a quarterly basis, the volume of imports declined by 7 percent (third quarter of 1948 to third quarter of 1949).

It seems probable that the high income elasticity of imports in short cycles is associated with inventory fluctuations which dominate both these short cycles and the volume of imports during them. Chart 1, which compares changes in the total volume of United States inventories with the volume of imports cor-

\section{CHART 1}

Inventory and Import Fluctuations

in the United States, 1946-50

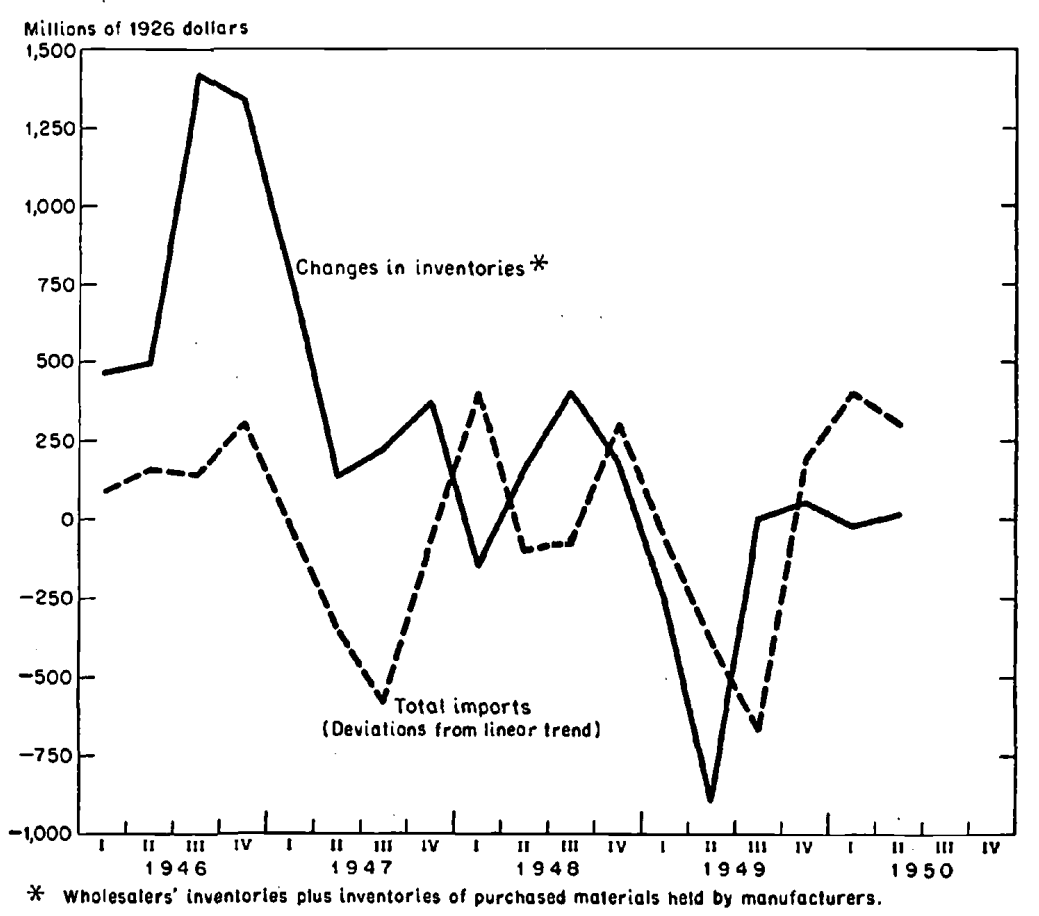


rected for trend, indicates an exceptionally clear relationship between the volume of imports and inventory changes, which warrants more intensive and rigorous investigation. It is not the "goodness of fit," however, which is the most striking attribute of the chart. Even more interesting is the consistency with which imports lag inventory fluctuations-generally by about one-quarter. This consistency of lag tends strongly to support the hypothesis that inventory fluctuations explain the short-run fluctuations in imports.

Our primary concern in this paper is with projections for a relatively long run. In that connection, inventory fluctuations and associated fluctuations in imports, which appear to be characteristic of very short cycles, are not of importance in themselves. But, if undetected, they are important as disturbing elements in the correlation; and, if properly allowed for, they will improve the correlation and lead to more reliable forecasts, even though it is (or has to be) assumed that these short-run fluctuations do not play a role in the period for which the forecast is made.

\section{Summary}

We have indicated two important respects in which import correlations may be improved. But mere correlation of total imports with a few more explanatory variables than have hitherto been used will not automatically yield a satisfactory basis for forecasting imports. A much more intensive study than has been made so far of the imports of individual commodities or the imports from countries or areas is likely to shed a good deal of additional light on the factors which determine imports. It is not obvious that the detailed analysis of a great many commodities will lead to a more reliable forecast than can be made on the basis of reasonable aggregates; but such an analysis by commodities will probably contribute to finding the most effective way of deriving the best estimate from these aggregates. ${ }^{91}$ In making these forecasts it will be realized that we have outgrown the marginal propensity to import as a general-purpose statistical coefficient -though its usefulness as an analytical tool in economic models is by no means exhausted.

Since the United States is the dominant buyer for many world

31 The importance of changes in inventories, for instance, became quite clear as a result of an unpublished International Monetary Fund study prepared by Mrs. M. Holzman, on the imports into the United States of many individual commodities. 


\section{THE INTERNATIONAL SECTOR}

market staples, there is a strong positive correlation between the volume of imports and the prices at which they are purchased. To the extent that one relies only on this (supply) relationship in forecasting United States import prices, one might just as well estimate the value of imports directly on the basis of those internal United States variables which are believed to explain fluctuations in the volume of imports.

The preceding discussion has been concerned mostly with factors which explain changes in the volume of United States imports. Where the objective is to project GNP or the balance of payments in value terms, imports would also have to be projected in such terms. The best procedure for this may be to project the prices of imports separately, in addition to the volume of imports.

\section{EXPORTS}

In the previous section we have discussed the methods to be employed in explaining (with reference to the past) and in forecasting (with reference to the future) the value of U.S. imports. We have shown the difficulties involved in this operation and pointed toward some unsatisfactory aspects of the work done in this field. But in spite of difficulties and errors, the explanation of fluctuations in U.S. imports is not fundamentally different from the explanation of fluctuations in any other part of GNP. Refinements in technique may be required and, no doubt, in due course be applied; but the entire explanation of U.S. imports runs in terms of variables which themselves are part of the U.S. economy. These include national income or GNP itself. In this respect import forecasting is no different from the forecasting of any other sector in the social accounts, in that the part depends upon the whole, and some knowledge, or provisional estimate, about the whole is necessary before the part can be estimated. This diffculty is faced everywhere, and it can be met by successive approximation, by assumption, or sometimes by policy decisions with respect to the whole. In this respect, therefore, the forecaster of U.S. imports faces no problems different from those that confront, say, the forecaster of the demand for automobiles.

When we pass over to exports, we enter into an entirely new field. The decision to buy U.S. exports lies primarily abroad..$^{32}$ In

32 We leave out of account here the donated exports like lend-lease, 
order, therefore, to explain U.S. exports, we shall have to explore and bring into our system the decisions and reactions of nonresidents. The amount on which these decisions bear is substantial: $\$ 12$ billion in commodity exports alone in 1949, nearly 6 percent of the total national income. To make sensible forecasts about these exports, we shall have to know both the underlying situations abroad and the responses of foreigners to these situations with respect to U.S. exports.

It might be thought that the most convenient and most logical way to explain U.S. exports would be to parallel the explanation of U.S. imports. Correlate the income of the world outside of the United States with U.S. exports and you have your relationship, symmetrical to the import equation, which would determine the magnitude of U.S. exports. This procedure was actually followed by Hinshaw and Metzler ${ }^{33}$ and by Tinbergen; ${ }^{34}$ but it is obviously unsatisfactory, because the "marginal propensities to import from the U.S." of different countries are so widely different that the aggregation of their national incomes for this purpose is not permissible.

But what if we took the national incomes of individual countries and applied to them individually some "marginal propensities to import from the U.S."?35 It would appear that even this procedure-would not work out very satisfactorily for a variety of reasons:

1. In many countries imports are at present subject to quantitative restrictions and the size of imports is, therefore, not only (and as to its short-run fluctuations, not primarily) determined by the demand for imports on the part of its residents, but also (rather) by governmental decisions as to the stringency of the controls.

United Nations Relief and Rehabilitation Administration shipments, or gift parcels.

${ }^{33}$ Randall Hinshaw and Lloyd A. Metzler, "World Prosperity and the British Balance of Payments," Review of Economic Statistics, Vol. xxvir, November 1945, pp. 156-70.

a4 J. Tinbergen, "Some Remarks on the Problem of Dollar Scarcity," paper presented to the International Statistical Conference in Washington, September 1947, Proceedings of the International Statistical Conferences, Vol. v, pp. 73-97.

${ }^{35}$ An interesting attempt in this direction is made by $\mathrm{J}$. H. Adler in "The Postwar Demand for U.S. Exports," op.cit. In an attempt to explain fluctuations in U.S. exports, Adler weights fluctuations in industrial production in foreign countries by their average share in U.S. exports. 
2. Even in situations where the government exercises no direct control on imports and where, therefore, the relationship between national income and imports may be presumed to be operative, it may not be particularly fruitful to consider imports as a function of national income. Indeed, in many countries it is probably more reasonable to read this relationship in the opposite direction: the possible value of imports determines the possible level of national income. This level of national income is then brought about by the government's monetary policy, in particular its banking policy and its fiscal policy. Often the equilibrium situation is reached by trial and error; if the monetary policy is too expansionist, reserves dwindle and the policy is then adjusted to the country's possibilities.

3. But even where income is freely determined by market forces rather than by government policy, and where no restrictions are imposed on imports which are demanded on the basis of this level of income, how do we know the level of income to be used in forecasting U.S. exports? Would it be necessary to estimate GNP or national income for all other countries, or to estimate the world's income by a set of simultaneous equations, in order to estimate the exports and the income of the U.S.? To some extent this is indeed the case. But certain short cuts are possible which will enable us to have a reasonable knowledge of U.S. exports without going through the estimation of the national income of all the countries of the world. The reason for this is that, in most foreign countries, factors coming from abroad are the most important factors responsible for fluctuations in national income and, hence, in imports; and quite often these factors outweigh domestic factors in the explanation of changes in imports.

It is, therefore, possible to bring to bear the weight of foreign decisions on U.S. exports without knowledge of the national incomes of foreign countries. There is also much to be said from the purely statistical point of view for an approach which does not hinge on the use of national income data for all countries of the world. In too many countries this sort of statistics is absent or available only in a very rudimentary stage; and, in some countries, national income data, including considerable sections reflecting production outside of the market sphere, are probably a poor indicator in any case of the demand for imports.

We shall indicate below the outlines of a method to estimate 
U.S. exports by means of a world system of relationships. The significance of this system lies in its application for long-run forecasting rather than short-run forecasting. For the short run, say, the next year or two, one might well obtain better results by making reasonably informed guesses as to what each country would import from the U.S. But even in making such guesses, it would be helpful to have as a background the knowledge of the relationships in such a general system, although for the short run, information concerning a variety of special factors, such as the inception of a particular development program, the postponement of certain categories of imports, etc., is likely to be more important for accurate forecasting than the ability to make refined allowance for longer-run tendencies.

When we suggest procedures for forecasting or planning the value of U.S. exports, it is obvious that we are dealing with a subject of far greater intrinsic importance than the magnitude of U.S. exports alone. We are dealing with the progress of development abroad; with the balance of payments of whole areas, such as Europe and the Far East; with the conditions for convertibility of currencies or the continuance of discrimination; and, as far as any foreign aid or foreign lending program is concerned, also with U.S. budgetary aspects. We are touching, moreover, in the present world situation on a problem of profound military importance, both in the narrow sense that investment goods exported may have to be produced at the expense of certain military items, and in the much more fundamental sense that an adequate plan for the development of underdeveloped countries may constitute a long-run substitute for military expenditure.

In constructing our model, we must choose the country as our unit. Our intention is to find rules concerning the behavior of countries with regard to their imports. Initially, we shall concentrate on total imports and then separate imports from the United States from these. But can we reasonably speak of the "behavior" of a country in international economic relations as if it has any similarity to the behavior of a consumer, or a firm, or an industry? When we refer to the behavior of a country, we try to reflect in one expression three different sets of behavior:

1. In the first place, there is the behavior of its residents, which we could register for each person individually but which, for reasons of convenience and the availability of statistical data, we 
aggregate by countries and sometimes by regions. We could, if we wanted to, study separately the exports from the U.S. to each Canadian province; but it is more convenient to consider all Canadian residents as a group in a study of U.S. exports. If governments followed a neutral monetary policy (whatever that may mean precisely) and did not apply any restrictions to international trade, the behavior of a country would simply be an expression for the aggregate behavior of all its residents.

2. We should take account also, however, of monetary policy measures taken by the government of a country in the light of that country's balance of payments situation. These measures may affect income and thereby imports. Sometimes they may be direct measures, such as the institution or retardation of a government's development program; sometimes these measures are more general, the government operating through bank credit, the money supply, taxes, or government expenditure.

3. The government may operate directly on foreign trade rather than through the more general economic variables which determine imports. These latter measures may include such restrictions as import quotas, tariffs, and multiple exchange rates. In our present context, we are little interested in the measures, and more in the effects which they are expected to achieve.

When we speak, therefore, of the behavior of a country as an element in a foreign trade model, we refer to these three aspects of this behavior.

\section{Factors determining other countries' imports}

\section{a. EXPORTS}

Among the factors which will primarily determine most countries' (though not the United States') behavior with respect to their imports is the value of their exports. Let us first consider a country whose foreign exchange reserves are at an "equilibrium level." It is not suggested that this implies that the reserves are "adequate" in any absolute sense of the term. For reserves, as for imports, the concept of certain absolute requirements, while useful for programs and plans, is quite unusable to describe the behavior of a country. Therefore, when we refer to an equilibrium level of reserves, we mean this in the sense of what the responsible authorities in the country consider as the amount which the country "can afford" and "must afford."

Let us assume that there is an increase in exports which is not 
offset by a reduction in domestic demand. This increase will raise incomes by the same amount and it will also affect imports through the three channels of behavior which we have just indicated. The income of exporters will go up and, through the wellknown multiplier mechanism, this will lead to an increase in imports. In terms of the simplest multiplier equation, the increase in imports will be less than the increase in exports, provided the marginal propensity to save (or the "marginal propensity to excess-save," or the "marginal propensity to hoard") is greater than zero.

Assuming that this marginal propensity is thus in excess of zero, the country's foreign exchange reserves will go up and the government is likely to stimulate or permit more expansionist developments, thus further increasing the demand for imports.

In those countries where the government relies on restrictive methods at the trade level, it will also attempt to relax these restrictions, increase quotas, lower tariffs, etc.

It is not of great importance for our model in the first instance by which of these three channels the change in exports leads to an increase in imports. In fact, it is most convenient for us if we can combine the reactions through the three channels into a single parameter indicating the behavior of the country. I have indicated this parameter as the "international reflection ratio." It indicates the magnitude in the change in imports which woul. come about in response to a change in exports. If $M$ stands for the value of imports and $X$ for the value of exports, then the international reflection ratio would be defined as follows:

$$
\rho=\Delta M / \Delta X \text { or } \Delta M=\rho \Delta X
$$

If account is taken only of the reactions through the behavior of individuals and the simplest multiplier pattern is followed, it will readily be seen that

$$
\rho=\frac{m}{m+s}
$$

where $m$ is the marginal propensity to import and $s$ is the marginal propensity to save. This expression $<$ unity if the marginal propensity to save is positive. Even then, however, $\rho$ will tend to approach unity as reactions through the second and third channels come into play.

${ }^{36} \mathrm{~J}$. J. Polak, An International Economic System (University of Chicago Press, 1953). 
The use of a single parameter to describe the behavior of a country does not imply that the country's response to a particular change will always be the same or will be constant over time. Statistical measurements of $\rho$ have actually been made with some measure of success, ${ }^{37}$ but these measurements are of no particular concern to us in this context. For planning purposes, it will be necessary to have a figure for $\rho$. Possibly it can be obtained from observation of the past; perhaps it can better be estimated in some other manner. In any case, it is probably safe to say that a great many countries have such urgent development needs and are so keenly aware of them that they have a persistent tendency to overimport; in these countries $\rho$ is likely to be very close to unity. Most of them have a very low marginal propensity to save, which would make for a value of $\rho$ of close to unity on account of individual behavior alone; and whatever increases in reserves are left over are likely to be used by the government.

\section{b. LONG-TERM CAPITAL MOVEMENTS}

With reference to the past, long-term capital movements may be taken into account in a manner quite similar to that for exports, so that only the total supply of foreign exchange needs would be considered. This procedure is justified because, in the past, it was normal for the total financing of any capital project to come from abroad. Thus a foreign loan of $\$ 1$ million would tend to lead to investment of the same amount, and hence income of the same amount (less the import component of the investment). Foreign investment of $\$ 1$ million would then presumably have roughly the same effect on national income and on imports as exports of $\$ 1$ million.

This simple equivalence of long-term capital imports and exports cannot be assumed to hold with respect to the future. The International Bank for Reconstruction and Development, for instance, does not normally lend to a country the total cost of an investment project, but only the import cost. ${ }^{38}$ Until recently, it

37 ibid.

${ }^{38}$ Article IV, Section 3(c) of the Articles of Agreement of the IBRD reads as follows on this subject: "The Bank, if the project gives rise indirectly to an increased need for foreign exchange by the member in whose territories the project is located, may in exceptional circumstances provide the borrower as part of the loan with an appropriate amount of gold or foreign exchange not in excess of the borrower's local expenditure in connection with the purposes of the loan." 
was the Bank's policy never to lend for any local currency expenditure in connection with a project. While this policy has now been relaxed, it will continue to be true-and indeed it is desirable-that the value of the projects sponsored by the IBRD will exceed the amount lent by that agency. ${ }^{39}$ National legislation in many countries limiting the extent of foreign participation in new industries may also tend in the same direction. It will, therefore, be necessary to make allowance for the fact that, in the future, a capital import of amount $L$ should not, in its effects on imports, be considered as equivalent to an export of the same amount $L$, but rather to $e L$, where $e$ stands for the "expansion ratio," that is to say, the ratio of additional investment to additional foreign capital.40 This expansion ratio is not constant, either between countries or over time. It will, in each case, depend on the whole nature of the country's borrowing plan. We may, therefore, write $^{41}$

$$
M=\rho(X+e L)
$$

\section{USE OF RESERVES}

For purposes of forecasting U.S. exports in the early postwar years, it seemed reasonable to assume that foreign countries would use up virtually all their available resources: the proceeds of their dollar exports, loans, grants, and whatever dollar reserves they felt they could spare. The events of these years seem

89 Allowance should also be made for the fact that the financing of a particular project with foreign capital does not necessarily indicate a net increase of investment over what it would otherwise have been.

${ }^{40}$ See J. J. Polak, "Balance of Payments Problems of Countries Reconstructing with the Help of Foreign Loans," Quarterly Journal of Economics, April 1943.

41 We pass from the somewhat clumsy equation in terms of $\Delta M$, etc., used in (1), to this form in terms of $M$, etc. It should be understood that all equations are assumed to be linear only in the neighborhood of present values for the variables and that these variables should, accordingly, be considered as differences from present values.

A theoretical point needs to be made here, to which Mr. C. D. Finch of the staff of the Fund has drawn my attention. With respect to exports, we express all the resultant expansion of imports through the coefficient $\rho$, whether the expansion is brought about directly through the behavior of individuals or indirectly through governmental responses (Section C-1-a). For foreign investment, however, governmental responses are indicated by the expansion ratio $e$, so that, with reference to the term $e L$, the reflection ratio should be limited to the first item, i.e., $m /(m+s)$. It may be noted that the maximum expansion ratio is $(m+s) / m$, so that the maximum for peL equals $L$. It seemed more convenient to deal with this point in a footnote than to complicate the formulae to allow for it more explicitly. 
to lend particular credit to Kindleberger's account of the chronic dollar shortage as a world-wide problem, an account which may perhaps, with slight oversimplification, be phrased: "All other countries will always have a dollar shortage because they will want to spend more dollars than they earn or have."

The experience of 1950 , when almost all foreign countries increased their holdings of gold and dollars (by a total of $\$ 2.8$ billion), must have come as a shock to those who believed in this relatively facile explanation of U.S. exports. There had, however, been numerous indications that this explanation was quite inadequate, at least as far as the European countries were concerned, and reflected only the very peculiar conditions of the early postwar period. Thus, Italy, which had ended the war with virtually no reserves, had acquired $\$ 200$ million in dollars in 1946 , nearly $\$ 300$ million in gold and all foreign exchange in 1948 , and $\$ 350$ million in gold and all foreign exchange in the course of 1949. While countries had shown themselves prepared to run payment agreement debts up to the limits provided by these agreements in 1946, 1947, and 1948, many of the credit and even grant facilities provided under the Intra-European Payments Scheme of 1949-50 failed to be taken up. There was quite a bit of evidence, therefore, before 1950, that international trade could not be explained in terms of an insatiable hunger for imports limited only by the availability of funds. The desires to acquire reserves, to curb inflation, and sometimes to provide protection to domestic industries all played roles in determining the magnitude of imports.

It may be that the accumulation of dollars and gold abroad in 1.950 represents, in part, a lag. Foreign individuals and foreign countries simply have not yet had the time to adjust their spending plans to the increase in income and reserves. In fact, this may be the most important explanation for the accumulation of reserves as far as the underdeveloped countries are concerned; for these countries, I believe, the "Kindleberger effect" is probably the rule rather than the exception. As far as the developed countries are concerned, however, the increase in reserves should be considered primarily as reflecting a deliberate policy. The period 1946-49 was abnormal in the sense that during that period many European countries held "excess reserves," which they gradually used up to finance imports. It may appear odd to speak of "excess reserves" in a time when reserves were low by all stand- 
ards of adequacy. They were high, though, by one standard: the urgency of the import needs which they could meet. It seems reasonable to consider countries, or perhaps rather governments, as having an indifference curve linking the level of available resources (from both imports and domestic production) to the level of their reserves. This curve would presumably cut the reserve axis at some point where available resources fall far below normal. At that point countries would be prepared to go into short-term debt to keep up the current flow of supplies. On the other hand, the curve would probably rise pretty steeply after some more or less normal reserve had been obtained. Not much more can be said about this curve, but it is important to realize its existence. The adjustment from actual reserves to the "desired reserves" at any particular stage is not immediate. The "excess" is not likely to be spent in a few months. It is budgeted over the future, taking into account not only the present, but also the future, level of desired reserves.

We can consider the period of $1946-49$ as one of generally, although not continuously, increasing income and hence gradually increasing "minimum reserves." At the same time, actual reserves for most countries continued to be in excess of minimum reserves and reserves continued, therefore, to be drawn down.

It would not be fruitful to pursue this point further in general terms. Enough has been said to make it clear that we should add to our import equation an allowance for the amount of excess reserves used during the period under consideration. We shall indicate this amount by $R_{E}$. It is clear that this symbol will stand for a positive amount when reserves are being run down, i.e., when actual reserves are in excess of "desired reserves," and for a negative amount when the reverse situation prevails. ${ }^{2}$ We then obtain the following equation for imports:

$$
M=\rho(X+e L)+R_{E}
$$

It will now be necessary to pass from total imports to the imports from one particular country, the U.S., in the problem which concerns us. For this purpose, let us indicate by $a_{i j}$ the fraction of country $i$ s imports which it buys from country $j$. The sum of these

42 Logically, $\boldsymbol{R}_{E}$ might be derived as an endogenous variable of the system. But there is a pretty narrow limit beyond which it does not pay to allow in the system for more and more relationships and hence to be burdened with more and more residuals, as these relationships do not hold exactly. 
fractions over $j$ will obviously equal unity. We then have the the following equation for $M_{i j}$, the imports of country $i$ from country $i$ :

$$
\begin{gathered}
M_{i j}=a_{i j} M_{i}=a_{i j}\left[\rho_{i}\left(X_{i}+e_{i} L_{i}\right)+R_{E_{i}}\right] \\
(i=1, \ldots, n ; j=1, \ldots, n ; i \neq j)
\end{gathered}
$$

When we introduce the coefficient $a_{i j}$, we do not intend to indicate a purely statistical fraction. Rather it is implied that this coefficient has a certain degree of constancy. This assumption appears justified on the basis of the considerable stability which appears to exist in the pattern of international trade. To be sure, there are long-run shifts reflecting the emergence of new import-trading countries, new consumer demands, and new techniques; and also short-run disruptions, in part on account of the overvaluation or undervaluation of individual currencies. For reasons such as these, it would not be wise to lift the $a_{i j}$ s for our forecasting purposes from, say, the interwar period. In order to do a reasonable job with reference to forecasting for a rather long period, it will be necessary to take account, as best one can, of knowledge of the shifts. It might be relatively less important to make allowances for the effects of improperly valued currencies. The reason for this is that one ought to assume that, in the longer run, improperly valued currencies will not persist: overvalued currencies will tend to come in for devaluation, and undervalued currencies will tend to lose their special advantage both by increases in prices and by the devaluation of other currencies.

The set of equations shown by (5) indicates all trade flows considered from the import side. Thus it contains some $n(n-1)$ equations explaining the same number of trade flows. In the light of what we have said earlier, it does not seem reasonable to use the same explanation for the United States imports, since these are to only a very minor extent determined by the factors listed.

It is readily seen that this set of equations also provides the exports from each country to each other country and, by summation over the second subscript, the total exports of any country. Thus the exports of country $k$ would equal $\Sigma k M_{i k}$, and if we take $k$ to stand for the U.S., this would provide the answer to the question that concerns us: the estimation of U.S. exports.

While the determination of the magnitude of a country's exports from the importing country's side appears a reasonable 


\section{THE INTERNATIONAL SECTOR}

procedure as far as the industrial countries, including the U.S., are concerned, it may, in some instances, yield unsatisfactory results for countries whose exports consist of a few raw materials. Within moderate limits our equations may satisfactorily explain the exports of this sort of country also. But if the equations indicate great changes-in particular, great increases-it may be doubtful whether the productive facilities of these countries in their particular export industries will be able to meet such demands. If they are not, the export forecast may be relatively far off, but it cannot be said in advance in which direction it will be off. An attempt to satisfy increases in demand will tend to lead to sharp price increases if the demand is highly inelastic. The export value of the raw material countries will increase much more than if productive facilities have been expanded to meet the increased demand. If, on the other hand, the demand is very elastic-for instance, because there are good substitutes for the particular commodities-the export value may be very much less than if capacity has been expanded in anticipation of the increase in demand.

These objectives point to the necessity of checking the total export figures forecast for particular countries against the likely production possibilities of these countries, and possibly of modifying to some extent our figures in the light of these checks. This type of correction is again not different from that necessary in the forecasting of certain segments of the domestic part of GNP. ${ }^{43}$

There are $n(n-1)$ equations of type 5 to determine $n(n-1)$ trade flows. These equations are adequate to express the relationship of trade flows in terms of each other, but not to determine the absolute amount of any one of them.

We may assume, however, that we know the value of U.S. imports and its distribution. On the basis of the internal variables of the U.S. economy, we can then (with $L$ and $R_{E}$ as autonomous variables) solve the system and obtain the value of any $M_{i j}$ as well as that of the exports of any one country. In other words, we have, at least ideally:

$$
\begin{gathered}
M_{i j}=F_{i j}\left(M_{k} ; e_{i} L_{i} ; R_{E_{\hat{\imath}}}\right) \\
(i=1, \ldots, n ; j=1, \ldots, n ; i \neq j)
\end{gathered}
$$

43 The reader will notice that these corrections are necessary because prices have not been brought into the system explicitly. They could have been introduced, but there is some risk in introducing additional parameters about whose magnitude we do not-and, perhaps for a long time to come, cannot-have any reasonable knowledge. 
in which each trade flow is expressed as a function $\left(F_{i j}\right)$ of U.S. imports, the capital import and expansion ratios of each country, and the excess reserves of each country. In this expression $F_{\text {is }}$ depends on all the $a_{i j}$ 's in the system as well as on the $\rho_{i}$ 's; and the partial derivative $\partial M_{i j} / \partial M_{k}$ is constant if equations 6 are linear. In other words, increases in U.S. imports will pull up the entire system of trade flows, and, assuming a constant proportional distribution of these imports, the increases in all trade flows will be proportional to the increase in U.S. imports. If, to give an example, the increase in U.S. imports from $\$ 8$ billion to $\$ 9$ billion raises exports from Belgium to Chile in the situation by $\$ 1$ million, then a further $\$ 1$ billion increase in U.S. imports (from $\$ 9$ billion to $\$ 10$ billion) will raise Belgian exports to Chile by another $\$ 1$ million. ${ }^{44}$

\section{d. PRACTICAL USE OF THE MODEL}

It is believed that the model, in the form in which it has here been presented, cannot be used for immediate practical application; that is, to arrive at precise forecasts. A considerable amount of work would be required to attain estimates for the $a_{i j}$ 's even when countries are grouped into areas; and it may be difficult indeed to obtain reliable estimates of these coefficients, which are marginal, not average, propensities. ${ }^{45}$ But even before the information necessary to use the model for forecasting is available, the model itself can be used to obtain qualitative conclusions which may be of great importance for balance of payments forecasting and, perhaps, of even greater importance for balance of payments planning. Some of these conclusions have already been touched upon, but they may be restated here in a somewhat systematic form. Individual conclusions refer to partial effects; that is, they are valid only on the assumption that all of the other factors remain unchanged. Thus, when speaking of changes in the magnitude of U.S. imports, we assume their distribution to be constant; and when we speak of changes in the distribution of U.S. imports, we assume total imports to be constant.

An increase in U.S. imports will lead to a smaller increase in U.S. exports. ${ }^{46}$ This is so because (or if one prefers, on the as-

14 In this statement, no account is taken of the effect through $R_{E}$, which, in some instances, may be important. For this reason, the fraction $\partial M_{1} / \partial M_{k}$ is written as a partial derivative.

45 If $i$ stands for a country then $a_{i 1}$ is zero; but if $i$ stands for an area, $a_{44}$ is positive, reflecting the marginal intratrade of the area.

46 This is a ceteris paribus statement. If U.S. foreign investment increases 
sumption that) the average of the $\rho$ 's in the system is less than unity. A further factor tending in this direction is that a general increase in U.S. imports will increase the general level of wellbeing in other countries and thus raise the level of "desired reserves." This in turn will render $\boldsymbol{R}_{\boldsymbol{E}}$ negative.

Subject to one important qualification, an increase in U.S. lending will increase U.S. exports more than an equally large increase in U.S. imports. This is so for a variety of reasons: (a) U.S. lending tends to be, to some extent, tied by either legal or institutional arrangements; (b) some U.S. lending, especially that through the IBRD, will have an expansion ratio greater than unity; (c) U.S. lending tends to be concentrated more than U.S. imports in countries which have a relatively high marginal propensity to import from the U.S.

The important qualification to this general statement is that it applies only to such lending as leads to additional investment which otherwise would not have been undertaken. It is limited, therefore, to what might be called project loans in the narrow sense of the word, in that the project would not have been undertaken had it not been for the lending.

The effect of increased U.S. imports on the increase in U.S. exports will be greater the larger the reflection ratio of the country from which the imports are obtained and the larger the marginal share of imports from the U.S. in imports of this country. It will readily be seen that if the U.S. increases its imports from a country $i$ where $\rho_{i}$ equals unity and $a_{i k}$ equals unity (the subscript $k$ standing for the U.S.), the entire increase in the foreign supply of dollars would come back at once as an increase in U.S. exports. In a long-run equilibrium analysis, account should be taken not only of the immediate return flow, but also of the indirect effects through third and fourth countries. If all $\rho$ 's were unity, or if the appropriate average of them were unity, it would be immaterial where the initial expenditure by means of U.S. imports was made, because, ultimately, all of the dollars would tend to flow back to the U.S. But it may even be that the difference from unity of the $\rho$ 's in the system is so small all over the world that it will make little difference in the equilibrium situa-

at the same time, the statement should be amended to read: An increase in U.S. dollar availabilities from increased U.S. commodity imports and capital exports will lead to a smaller increase in U.S. exports (vide point 4 in Mr. Fabricant's Comment). 
tion where the U.S. spends its money for imports, so far as the ultimate effect on the total value of U.S. exports is concerned. The distribution of U.S. imports and lending is of much greater importance for the total flow of world payments than for the value of U.S. exports. It might be inferred from the preceding paragraph that it would be desirable for the U.S., all other things being equal, to concentrate its imports in the countries for which $\rho_{i} a_{i k}$ is the highest. This conclusion would be justified if the objective of U.S. imports and lending were to maximize U.S. exports-and even then, the justification for the conclusion might not be strong if the $\rho$ 's all over the world were close to unity. But it does not seem reasonable to assume that the objective of U.S. imports and lending is to maximize U.S. exports.

Apart from the direct objective of individual U.S. imports and individual acts of U.S. lending abroad-to obtain particular commodities or particular investments, or to stimulate particular development possibilities in foreign countries-the general objective of the U.S. supply of dollars may reasonably be described by reference to one of the purposes of the International Monetary Fund: "to facilitate the expansion and balanced growth of international trade and to contribute thereby to the promotion and maintenance of high levels of employment and real income and to the development of the productive resources of all members as primary objectives of economic policy." 47

In many areas of the world, trade is restricted below the optimum on account of inadequacies of reserves. In a sense, the supplying of dollars by the United States may be considered as a method to oil the mechanism of international payments. Obviously this purpose is not well served if the lubricant flows back as quickly as possible to the place from which it came. It is best served if the lubricant stays in the mechanism for a long time, finding its way through all the channels of trade all over the world. From this point of view, it would be desirable if payments on account of U.S. imports and U.S. lending were directed to countries that (marginally) obtained a minimum of their imports from the U.S. and a maximum from other countries. In other words, U.S. payments should, from this point of view, be directed to countries with a minimum $a_{i k}$ as well as to countries with a maximum $p_{t} .^{48}$

47 Articles of Agreement of the International Monetary Fund, Article I (ii). 48 A comparison-somewhat limping, as are all comparisons-might be 
The balance of payments of the U.S. cannot be explained or forecast by reference to U.S. factors alone. In order to build up our model, variables and parameters relating to foreign countries have to be taken into account. The plural foreign countries (or foreign regions) is essential. No useful purpose is served by opposing to the U.S. a magical "rest of the world" whose balance of payments can be obtained by the easy trick of changing the debit and credit headings in the U.S. balance of payments. This "rest of the world" represents nothing at all in terms useful for economic analysis. It is an amorphous aggregate about the behavior of which no useful statement can be made.

This is perhaps most strikingly indicated with regard to reserves. The observation that the reserves of one particular country, say, France, have increased has a very definite economic meaning and may lead to certain definite consequences. It does not matter for this purpose whether the reserves of all French banks or all French business concerns have come up. Certain action by the French government may be expected in response to the change in the country's reserve position. On the other hand, the statement that the reserves of the "rest of the world" have gone up has very little meaning in terms of forecasting events which will follow from this fact. For: (a) the increase in reserves may have occurred in countries which heretofore have had small reserves, and it may then stimulate additional imports; (b) it may have occurred in countries which have had abundant reserves, in which case it is likely to have very little effect on imports; (c) the over-all increase may be compounded of a decrease in countries with adequate reserves and a greater increase in countries with highly inadequate reserves, in which case it may lead to a more than proportional increase in imports; (d) the over-all increase in reserves may be compounded of a decrease in the reserves of countries short of reserves and an increase in the reserves of countries with adequate reserves, in which case it may lead to a reduction in the imports of the rest of the world.

In order to be able to pass beyond meaningless statements of alternative possibilities like the preceding, it will be necessary

made with deficit financing policies. It is often argued that deficit financing does not "really" cost the government as much as it appears to cost because part of the additional expenditure will return to the government as additional tax receipts. But it would obviously be absurd to plan deficit financing by so directing the government's payments as to maximize the return from taxes in the first round, or even in all rounds. 
to have data on the balances of payments and the reserves of individual countries. The balance of payments of the U.S. taken by itself, read forward or backward, does not contain adequate information for our problem.

Similarly, the solution to the imbalance of world payments cannot be found by looking at the U.S. balance of payments alone. It is merely a truism to say that, if the balance of payments of the U.S. were brought into equilibrium, the "dollar shortage" would be over. While a situation of balance in the payments of the U.S. would ipso facto mean balance in the aggregate payments of the "rest of the world," this latter over-all balance could well be compounded of large deficits in some countries and equally large surpluses in others, and if there were no longer a dollar problem, the same balance of payments difficulties might crop up in the form of a sterling problem or a cruzeiro problem, or, simply and more generally, as problems of deficits and surpluses.

Useful balance of payments forecasting must be in terms of the behavior of countries, not simply in terms of definitional relations which can be derived from the social accounts. It is clear from the few equations shown earlier that they contain certain parameters which are intended to describe the behavior of countries. We are not presently concerned with the question as to how much we actually know about this behavior, how regular it is, and with what confidence it can be predicted. The important thing to bear in mind is that these coefficients reflect behavior. The risk of interpreting as causal relationships concurrent changes occurring in the various items in the social accounts is a general risk, and economists and statisticians alike have to be constantly aware lest they fall into the traps which they themselves set when they started out in the social accounting business. In the field of international payments, these risks are no smaller than in other fields of social accounting. With regard to problems such as the dollar shortage or discrimination, this sort of mistake is frequently made. ${ }^{49}$ In practice, the need for caution often does not go beyond avoiding the identification of average propensities with marginal propensities; but the problem is, in a sense, more funda-

49 In this connection I may mention, as an example, Ragnar Frisch, "On the Need for Forecasting a Multilateral Balance of Payments," American Economic Review, September 1947. Cf. my comment: "Balancing International Trade: A Comment on Professor Frisch's Paper," American Economic Review, March 1948. 
mental in that it is necessary to distinguish behavior from observed social accounting relationships.

\section{OFFICIAL LOANS AND GRANTS}

\section{Introduction}

We now come to the third important element in the balance of payments which we intend to discuss from the forecasting point of view: official loans and grants. These are entered as an "autonomous variable," $L$, in our system of equations above. We must now find an explanation for this variable.

Although the variable $L$ referred to loans and grants by all countries, this section will deal only with loans and grants by the United States. This is not to minimize grants and loans by other countries, in particular, capital exports by the United Kingdom in the form of releases of sterling balances. But we concentrate here on the loan and grant component of the U.S. balance of payments, not on $L$ as it affects U.S. exports.

\section{No forecast possible}

With regard to such balance of payments items as imports, exports, and tourist expenditures, it is often reasonably safe to rely on "persistence forecasting," i.e., to assume that natura non facit saltum, and that what happened recently is likely to continue to happen in the near future. This procedure is, however, particularly inappropriate in the field of foreign grants and loans, because they represent governmental decisions, which change abruptly from one year to the next. Perhaps the most striking example in recent history is the Marshall Plan. It is probably not unreasonable to say that in May 1947, United States aid to Europe for the year 1948 would have been forecast at a few hundred million dollars at most (outside Germany and Austria, and perhaps Italy and Greece). Yet, a few months later, after the Harvard speech of June 5, 1947 and after the Western European countries had presented a four-year plan for $\$ 17$ to 22 billion, it suddenly became reasonable to estimate this aid for 1948 at a number of billions of dollars. The difference between the two figures reflects a decision, and items which are determined by governmental decisions to such a large extent are obviously not suitable for pure forecasting by economists who are on the outside. 


\section{THE INTERNATIONAL SECTOR}

The sections which follow, therefore, do not deal with the forecasting of these decisions, or with methods of forecasting them. Rather they constitute an analysis of the possibility of basing the decisions on rational factors, failing which, one would have to consider them as a matter entirely outside the realm of economics. In these discussions we shall limit ourselves to the development aspect of foreign loans and grants. The period of reconstruction aid is largely over, except for Korea. Many of the same considerations apply, however, to aid for the two purposes, as the economic problems of reconstruction and development are comparable in many respects.

\section{Magnitude of the need}

It is tempting to seek "objective" figures on the amount of foreign aid required by reference to some standard of need, and it is easy to point to the disparity in per capita income between the underdeveloped countries, on the one hand, and Western Europe and the United States, on the other hand, to show the existence of a vast objective need for more capital. But how much? The underdeveloped countries of the Far East (outside China), Africa, the Near East, and Latin America, with a population of about 1,075 million, have a national income of about $\$ 80$ billion, or an average of $\$ 75$ per capita. For the United States, the figure is about 20 times as high. To raise these areas to the U.S. level would require additional income of roughly $\$ 1.5$ trillion. In the advanced industrial countries, the ratio of capital to income is about four to one. Thus, to produce this much more income, at least $\$ 5$ trillion might be needed, ${ }^{50}$ or $\$ 100$ billion a year for 50 years, assuming a stationary population and the increase of productivity in the underdeveloped countries to the U.S. level with an adequate supply of capital. Even on these assumptions, these countries would reach the 1950 level of the United States only in the year 2000, when the United States would be far ahead of this level.

These figures are presented partly to show the magnitude of the problem, but primarily to make clear by reference to the factors that it cannot usefully be considered from the point of view of absolute needs. This indeed is just as well. While economic planning must be based on statements of objectives which U.K.

${ }^{50}$ Using a somewhat lower ratio of capital to income than in the U.S. or 
it is desired to achieve, these objectives themselves do not have the absolute character of "needs" or "requirements" which can somehow be objectively determined. ${ }^{51}$ Calculations of "requirements" often deceive by their apparent objectivity those who use the figures as well as those who compute them. It should always be clear that they are nothing but derivations based on arbitrary assumptions, often of some average per capita level of consumption. Since import requirements are the difference between the computed consumption requirements and estimated domestic supplies and often have to be met at prices much higher than the domestic supply price, they are particularly subject to minor fluctuations in the postulated consumption levels. ${ }^{52}$

\section{What the United States can afford}

Just as the criterion of need does not give us a clue to the proper magnitude of a foreign aid program, so the criterion of what the United States can afford is equally an irrelevant and useless yardstick to apply. In connection with the Marshall Plan, the question of "the limits within which the United States could safely and wisely extend aid to Western Europe" ${ }^{39}$ was the subject of wide political discussion and of extensive study by a Presidential committee. But the report of the committee was devoted almost exclusively to the question of the availability of particular commodities, not to the ability of the United States to bear any particular amount of aid in general; and with the disappearance of the world wheat shortage shortly afterward, the entire problem of the ability of the United States to provide foreign aid of any given dollar amount seems to have vanished from public attention.

This is quite reasonable for two reasons. In the first place, the optimum practicable amount of foreign loans and grants for development purposes in the near future to all countries outside the U.S.S.R. sphere is likely to constitute only a small proportion of the United States gross national product. Whether the amount

51 Except in emergency situations and with reference to the most primary foodstuffs.

${ }^{B 2}$ A striking example: The computation of minimum meat requirements for the countries of Eastern and Southern Europe which received UNRRA supplies showed a difference in import requirements of a billion dollars a year, according to whether one or another recognized standard of minimum intake was used.

${ }_{53}$ European Recovery and American Aid (President's Committee on Foreign Aid, November 7, 1947), p. 3. 
is about $\$ 1.2$ billion as suggested in the Gray Report, or even, say, $\$ 5$ billion (which would be 6 percent of the national income of the countries concerned), it would, in any case, be within the range of 1 or 2 percent of the $\$ 300$ billion gross national product. ${ }^{54}$ Only if one were to consider large aid to Eastern Europe, the U.S.S.R., and China ${ }^{55}$ might the total figure for developmental loans and grants reach a high percentage of GNP-and such aid would then, most obviously, be in substitution of very much larger other demands on the national economy and on the budget. But secondly, and more generally, it should be realized that one cannot in any absolute sense (or in any sense whatever) speak of a country's "ability" to render foreign aid-any more than one can speak of a country's ability to spend money on education or on military preparedness. As put most explicitly in the Act for International Development, development is an objective of United States policy. ${ }^{56}$ This objective must be valued on the national scale of values. ${ }^{57}$ It must be weighed against alternative uses of United States resources. This process of weighing may yield a particular figure of the amount the United States is prepared to spend on foreign aid. But this should not be regarded as the amount which the United States can afford. Foreign aid figures of a number of billions a year would have been considered unthinkable 15 years ago. They are not unthinkable now, not because the United States is so much richer-although, of course, it is-but because of a change in the schedule of values.

\section{An optimum rate of capital inflow}

Does it follow, then, that there is no objective criterion to guide

54 For a more extensive discussion of the concept of "capacity" for foreign financing, see Horst Mendershausen, "Future Foreign Financing," Review of Economics and Statistics, Vol. xxxr, November 1949, pp. 272-74.

ss Something in the order of the $\$ 50$ billion, five-year plan proposed by Senator McMahon in February 1950.

so Public Law 535, Section 403(a) reads as follows: "It is declared to be the policy of the United States to aid the efforts of the peoples of economically underdeveloped areas to develop their resources and improve their working and living conditions by encouraging the exchange of technical knowledge and skills and the flow of investment capital to countries which provide conditions under which such technical assistance and capital can effectively and constructively contribute to raising standards of living, creating new sources of wealth, increasing productivity, and expanding purchasing power."

${ }^{57}$ Horst Mendershausen, "Foreign Aid with and without Dollar Shortage," Review of Economics and Statistics, Vol. xxxiI, February 1951, p. 43. 
the decision of policy makers-a decision which forecasters may try to forecast, or perhaps to influence? Or should one fall back on determination by such short-run bottlenecks as were often stressed by the International Bank for Reconstruction and Development in explaining the moderate rate of its lending in the face of enormous need: the lack of detailed plans acceptable to the Bank, or the lack of people who can make such plans? It would seem that considerations of this sort, however pertinent they may be to explaining developments in the short run, would have little place in the making of plans for the longer periodexcept that the plans themselves should provide for means to break the bottlenecks. No one would base the scope of a longrun program of disease control on the number of physicians presently available.

It would appear that there is such an objective criterion-although it is not precise and not subject to immediate statistical application; that, in fact, there is an optimum rate of foreign investment from the point of view of the countries receiving the capital.

It might seem at first sight that as far as capital-importing countries are concerned, forgetting for a moment about the service of the debt, there is no limit to the amount of capital they could absorb, or at least, that this limit would be so far removed that it would have no practical significance. Assuming investment to proceed at a rate no higher than the rate of foreign capital inflow, ${ }^{58}$ why should not each country seek to obtain the largest amount of investment and capital inflow that it can?

The answer to this question is primarily in terms of the mobility of goods, both within the country and internationally: it is the lack of mobility, or, in other words, the inelasticity of supply of goods within the country or within certain regions of the country, which sets important limits on the amount of capital a country can absorb.

Let us take the case of perfect mobility of goods, both internally and through imports from abroad, and further assume perfect elasticity of supply in the world as a whole-a reasonable assumption if the country whose problem we study is relatively small. ${ }^{59}$ An investment program of magnitude $I$ per annum is

$58 \mathrm{Or}$, indeed, no higher than the rate of foreign capital inflow times the maximum expansion ratio.

50 The assumption may not be quite so reasonable as far as the world 


\section{THE INTERNATIONAL SECTOR}

undertaken, of which $I_{m}$ is imported capital goods and $I_{d}$ is demand for domestic labor and supplies. The entire value of $I$ is made available in terms of foreign exchange by, say, a foreign grant. It is clear that $I_{m}$ raises no problem at all. The goods are imported against payment from the available foreign exchange and, until they begin to be unloaded and thus start to be combined with domestic resources, no call on those resources is made. As far as $I_{d}$ is concerned, this will lead to a secondary demand for consumer goods, both domestic and imported, and successive rounds of income spending. To the extent that the derived demand is for imports, there is again no problem: they can be financed from the balance of $I$ available. Indeed, assuming $\rho<1$ (or, more generally, $e_{\rho}<1$ ), some of the foreign exchange made available will remain unused. To the extent that the demand is for domestic goods, and their local supply is not infinitely elastic, these will flow in, with perfect mobility, from other parts of the country or from abroad. The price level of all commodities in all parts of the country will remain constant, as any infinitely small increase in prices would call forward additional supplies, either from other regions or from abroad. There is no limit to the investment, assuming the requisite foreign exchange accompanies it.

But this ideal situation is a quite inaccurate description of reality, particularly in underdeveloped countries. In such countries the cost of transport is high. Price differentials between regions are enormous. The cost to the consumer of imports is very considerably above their landed cost-if not because of tariffs, then because of high markups, monopoly-type profits of importers, expensive marketing. These factors make for a rather inelastic supply of consumer goods when, on account of increased demand, local supplies have to be supplemented by imports. Not until the local price rises substantially will importsfrom other regions or from abroad-begin to flow in. ${ }^{60}$ Thus,

supply of food is concerned in connection with large-scale development in all underdeveloped countries simultaneously.

${ }^{60}$ The rise in price occasioned by an increase in demand will be very much greater if the increase shifts the country (or region) from being a net exporter of, say, rice to being a net importer. The same high cost of transportation and trade make for a wide spread between the prices of export goods on the farms and in the villages, on the one hand, and at the export level (f.o.b.), on the other. Hence, for the consumer, the difference between the prices of rice at the rice "export point" and the rice "import point" ( to borrow gold standard terms) should be very large indeed. Or, 
investment will be accompanied by a rise in local prices even though adequate foreign exchange is available. Some inflation will occur.

Owing to the inflation, real income will be shifted from the population at large to the relatively small wealthier classes. If the money income rates of large sections of the population are relatively inflexible, the shift in income to the higher income groups might even exceed the increase in real income due to the additional investment. In that case, the purpose of the development program-to raise the real income of the low income groups -will be defeated. Hence the existence of an optimum point of foreign investment: the point at which the current loss in real income of the low income groups in the population because of inflation exceeds the discounted ${ }^{61}$ prospective increase in real income which may be expected from the new investment.

It is not suggested that a precise, or even a rough, figure can be set for each country or for the underdeveloped world as a whole on the basis of these theoretical principles. Their main justification at this stage is to point out that there is an optimum of this sort. The existence of an optimum can also be observed from the postwar experience of a country which has built a very high rate of investment on the basis of (or at least supported by) large foreign grants. The Philippines, from 1946 to 1949, devoted about 25 percent of its national income to investment. ${ }^{62}$ Assistance from the United States in various forms enabled the country for a number of years to proceed in this manner without balance of payments limitations. But it is doubtful whether this rate of investment, with the attending high level of prices, was to the benefit of the population at large. Indeed, it seems quite reasonable to maintain that the Philippines would have been better off with a lower rate of investment.

The fact that one country (or a few) ( $^{63}$ can be shown to have received more than the optimum rate of investment would tend to support the existence of such an optimum. But the optimum obviously does not exist in absolute terms-as $x$ percent of the

in other words, the elasticity of supply beyond the export point may be very small.

a1 Note that a rate of interest is implied-the (very high) subjective rate applicable to the low income groups in the underdeveloped countries.

a2 Economic Survey Mission to the Philippines, October 9, 1950.

${ }^{63}$ Greece also seems to be a case in point of a country receiving more aid than was good for its economy. 
national income. A great deal will always depend on the particular nature of the investment program. Above all, the limit will depend on the measures taken by the government to increase the elasticity of supply in the whole economy as well as on measures to increase savings. To give one example: A large public works program in which workers are paid money wages with which they bid up food prices until imports flow in may be seriously inflationary; while the same program may be perfectly tolerable if the government, with the foreign exchange available to it, purchases foodstuffs abroad and distributes them as wages in kind.

It is clear from this that an optimum rate of investment can be determined for each country only on the basis of a plan-not only of the cost and the nature of the program, but also of the manner in which it is to be carried out.

As these plans come gradually into being, and the experience of tolerable and intolerable rates and conditions of investment is gathered in various countries, it will become possible to obtain an impression of the magnitude of the optimum rate of investment.

It might be found that the distance between this optimum and the amount the United States and other capital-exporting countries are prepared to make available is not too great. ${ }^{.4}$ In our present state of knowledge, however, we cannot give any confident answer to this question.

C O M M E N T

Solomon Fabricant, New York University

1. From among the many interesting things in Mr. Polak's stimulating paper, I can select only a few for examination. There is, first, his proposal for projecting U.S. imports. The ratio of imports to gross national product has followed a downward trend in the past. Given a projection of GNP, he suggests, we may use an extrapolation of the trend in the ratio to project the trend in imports.

My first comment is on the historical trend in the ratio of imports to GNP. Mr. Polak notes the irregularities in the movement of the ratio, but concludes that "in any case," there is sufficient evidence for a downward trend. Yet the irregularities cannot be ignored when we are projecting one or two decades into the future. According to Polak's Table 3, the ratio changed between

${ }^{64}$ After making allowance for domestic saving and private capital imports. 
adjacent averages by the following number of percentage points: $-1.1,+0.2,-1.7,+0.4,-0.6,-1.6,-0.3$. The differences among these figures may seem small, but they must be referred to an average percentage of only 4 or 5 .

There is, next, the question whether the trend in the above ratio is a simple function of time. Would the ratio continue to fall whatever happened to GNP? Polak himself explains the downward trend by the rise in per capita income. If national income stopped rising more rapidly than population, the ratio of imports to GNP might stop falling. This suggests a revision of the formula for projecting imports.

But we can hardly stop here. Nor would Polak, for he appeals for a "more intensive study . . o of individual commodities" (Section B-6). This might take the form of an investigation of changes in the ratio of imports to output in each of our industries and changes in the relative importance of industries with high and low average import-output ratios. (This, too, is implied by Polak when he speaks of the declining ratio of imports to GNP as the result of increased self-sufficiency and of the rise of the service industries.) Then we would have to explain these changes, before we could use them as a basis for projecting total imports. And this explanation could not avoid bringing in certain developments abroad, so that the explanation of U.S. imports would not run in the simple terms of "variables which themselves are part of the U.S. economy" (Section C). It is safe to say that we would find the historical trend reflecting the net result of a number of forces acting in opposite directions, and that the weights of these forces have been shifting. Were such an analysis available, I am not sure that we would project a trend in the ratio of imports to GNP that continued to decline at the historical average rate, or even declined at all.

2. When it comes to projecting U.S. exports, Polak avoids the major task of dealing with the national products and other domestic variables of countries in the rest of the world by assuming that, unlike the United States, their national products are determined by their exports, and ultimately by the rest of the world's exports to the United States. To construct the projection formula for U.S. exports, it is necessary to derive a few parameters from data for other countries, but these "have a certain degree of constancy" (Section C-1-c). Fundamentally, the only explicit independent variable is U.S. imports. 
The justification for this is essentially the claim that "in most foreign countries, factors coming from abroad are the most important factors responsible for fluctuations in national income and, hence, in imports; and quite often these factors outweigh domestic factors in the explanation of changes in imports" (Section C). Here we have the rather widely accepted theory that the U.S. exports depressions (or business cycles). But even if we could have confidence in this explanation of fluctuations, it is difficult to see the justification for applying the argument to trends.

Polak is a little vague as to how the parameters are to be derived. Historical data are not satisfactory, for in contrast with the continuity of the U.S. situation, a great "structural" change has occurred in the outside world. The behavior patterns summarized by the parameters can be put only in terms of a new post-World War II set of habits: "a great many countries have such urgent development needs . . . that they have a persistent tendency to overimport" (Section C-1-a); unlike the past, the effect of capital imports must be multiplied by an "expansion ratio" (Section C-1-b); and so on. We may appreciate the need to recognize that the economic world has changed. Nevertheless, two questions require some discussion: first, why no allowance needs to be made also for important changes in the United States; and second, why the changes abroad must be viewed as revolutionary.

Having argued that the "coefficients have a certain degree of constancy," Polak goes on to admit that, "to be sure, there are long-run shifts reflecting the emergence of new import trading countries, new consumer demands, and new techniques; ...." (Section C-1-c); and to indicate his unwillingness to "imply that the country's response to a particular change will always be the same or will be constant over time" (Section C-1-a). This, it seems to me, takes the heart out of the argument that projections of U.S. exports can be determined primarily by reference to U.S. imports. Once changes in the parameters are admitted, Polak must also admit, as he in fact does (but only with reference to "rather long" periods), that "to do a reasonable job with reference to forecasting ... . it will be necessary to take account, as best one can, of knowledge of the shifts" (Section C-1-c). Polak does not define a "rather long" period; but, if it is one in which such changes may become too important to be ignored, my guess is that it is as short as two decades and possibly even one. 
3. Polak assumes that (private) foreign investment is determined by trade. There can, of course, be no question that imports and exports influence foreign investment. A country exporting railroad equipment and financing the export by loans raised within it provides an obvious example, and so does a country exporting oil and hoarding the royalty proceeds abroad. It is also true, however, that foreign investment influences imports and exports, and economists have been studying the mechanism for generations. But Mr. Polak assigns only "official loans and grants" to the role of independent variable. A major diffculty in projecting foreign investment stems out of the complex interaction between investment and trade, and Polak's assumption is an effort to skirt it. I wish it were that easy.

4. One of the conclusions drawn by Polak from his analysis is that "an increase in U.S. imports will lead to a smaller increase in U.S. exports" (Section C-1-d), other things remaining the same. This is mainly because ("or if one prefers," Polak is frank to say, "on the assumption that") foreign countries tend, on the average, to increase their imports less than their exports increase. As change in world imports equals change in world exports, it follows that increase in U.S. imports must be greater than increase in U.S. exports. Is the reasoning (or "assumption") acceptable? Consider the implications: the difference between changes in exports and in imports is (roughly) equal to the change in foreign investment; U.S. imports have an upward trend; therefore, on Polak's theory, there is a secular tendency for U.S. foreign investment to decline. This curious conclusion, it seems to me, can only raise doubts about the theory on which it is based.

5. In his discussion of the optimum rate of capital inflow, Mr. Polak reminds us that the simple aggregate of a nation's income is an incomplete criterion of its economic welfare. His own criterion is in terms of the "low income groups," the "bulk of the population," but I imagine he would not object to taking account of the whole income distribution. This would avoid arbitrary definition of "low income," would allow for inequalities at the lower end of the distribution (which some feel to be more injurious than the disparity between the very rich and the "bulk" of the population), and would give some weight (as most of us would wish) to the impact of development on the "high income" groups. Just what measure of inequality of income distribution 
is appropriate, where to secure the necessary data for its calculation, and how it should be weighted relative to the average level of income, when judging how far to push an investment program, are questions which reinforce Polak's own conclusion that his criterion is still in the "theoretical" stage.

If we are going to broaden our criterion, perhaps we should allow, also, for the enormous noneconomic costs of change in habits and places of working and living encountered by developmental programs. These costs might go as negative items into the calculation of average real income (with a weight base shifting as adjustments are made and new habits learned), or they might constitute a third element in the criterion. Their inclusion would not make application of the criterion any easier.

6. Mr. Polak's comment on the bottleneck criterion of optimum rate of capital inflow raises again the question of how long the short run is. To increase appreciably the number of physicians in a backward country, to use Polak's example, might well take a generation or more. But bottlenecks never disappear: they only change their form. Economic development is a process in which bottlenecks are constantly being discovered and broken. Education, trade connections, habits of work, commercial (and political) ethics, to speak only of "intangible" capital, must be improved. It is a slow process. This means that the rate of economic development must be planned and benefits of capital inflow must be calculated with an eye to these requirements. Development plans must have a time dimension; and every "optimum rate of capital inflow" also must be "dated." 
